\title{
A PÉNZÜGYI FELÜGYELETET ELLÁTÓ MNB ÉS A „QUAESTOR ÜGY”.
}

\author{
Lovas Dóra ${ }^{31}$
}

A 2014-es és 2015-ös évek a brókercégek, hitelintézetek hanyatlásának idöszakavoltak. ${ }^{32}$ Szinte minden ember rendelkezik bankszámlával, kötvénnyel, ezért egy ilyen helyzet rendkívül nagy hatással van az emberek vagyoni viszonyaira; továbbá azt is érdemes megjegyezni, hogy egy hitelintézet bukása nem csak közvetlenül, de akár közvetetten - például az államháztartásra gyakorolt hatásával, vagy a pénzügyi rendszerbe vetett bizalom megrendülésével - is okozhat károkat. Manapság sokat hallhatunk arról, hogy a MNB felügyeleti hatáskörében eljárva kezdeményezi egy-egy pénzügyi intézmény felszámolását, mivel Magyarországon a jegybank látja el a pénzügyi intézmények felügyeletét, amely többek között a 2007-töl kezdödö, Európában 2008-ban eszkalálódó világválságnak köszönhetö.

A válságot követően a tagállamok központi bankjai, illetve pénzpiaci felügyeleti szervei nem voltak képesek a pénzügyi válságot egyedül kezelni, azonban nem volt kialakítva olyan szabályozás, amely azt határozta volna meg, hogyan müködjenek együtt más intézményekkel. A válság felhívta a figyelmet az európai és a tagállami pénzügyi felügyelet gyengeségeire, valamint a válságot előrejelző és kezelő intézmények, mechanizmusok hiányára is. Az uniós kormányzati szinten hozott válságkezelö intézkedések keretében, a gazdasági és monetáris integráció megerősítése céljából ezért egy integrált, európai szintű pénzügyi felügyelet kialakításáról döntöttek. A válság hatására a bankrendszerben felszínre kerülő további ellentmondások kezelése több lépcsőben zajlott, illetve zajlik, különböző okokra és hatásokra visszavezethetöen.

A válság felkészületlenül érte az Európai Unió tagállamait, nem álltak rendelkezésre megfelelő mechanizmusok a bankok és befektetési vállalkozások kisegítésére, válságaik kezelésére, így azokat a tagállamok közpénzböl mentették meg. A tagállamok erösíteni szerették volna az egymás között fennálló bizalmat és együttmüködést (és a belső piac hitelességét), annak érdekében, hogy a bankválság által generált problémák ne vezessenek olyan megoldási kísérletekhez, amelyek egy ország gazdaságát és az országba vetett bizalmat meg tudják rengetni. A válságot megelőzően nem létezett a bankokra vonatkozó egységes elöírás, hanem többnyire a székhelyük szerinti tagállam joga határozta meg szabályozásaikat, és ez a helyzet számos konfliktushoz vezetett. Az eredménytelen megoldási kísérletek sorozata vezette a tagállamokat a szorosabb együttmüködésre, és az ilyen helyzetek elkerülése végett a bankszanálás új európai rendszerének a kidolgozására és egyes országokban a felügyeleti funkciók ellátásának megváltoztatására.

Az Európai Unió több tagállamában a válságot megelőzően nem volt megfelelő a pénzügyi felügyelet szabályozása, ugyanakkor uniós kormányzati szinten sem volt megoldás. A válságot követően erősödött az igény a felügyeleti elégtelenségek kezelésére. Uniós szinten felállították a makroprudenciális és a mikroprudenciális felügyeletet ellátó szerveket, így az Európai Rendszerkockázati Testületet, valamint a mikroprudenenciális felügyeletért felelős Európai Bankhatóságot, Európai Biztosítás- és Foglalkoztatóinyugdíj-hatóságot, illetve az Európai Értékpapír-piaci Hatóságot. Azonban igen hamar rájöttek, hogy a Rendszerkockázati Testület által végzett koordináció nem elég az európai pénzügyi piac töredezettségének

\footnotetext{
A tanulmány az OTKA K 101147 sz., A városi kormányzás közepes városokban és várostérségekben című kutatási projekt keretében készült. Kutatásvezető: Horváth M. Tamás.

${ }^{31}$ Lovas Dóra, egyetemi hallgató, DE-ÁJK

${ }^{32}$ Ld. http://www.psfn.hu/eljarasaink.html
} 
elkerüléséhez, melynek következménye lett az, hogy a Bizottság 2012-ben javaslatottett közzé a Bankunió létrehozása végett.

Tagállami szinten a válságot megelőzően egyes országokban a pénzpiaci felügyeleti funkciókat és a monetáris politikához kapcsolódó hatásköröket külön intézményi keretek között látták el, más országokban integrálták ezt a két funkciót, és szélesebb hatáskörrel ruházták fel a jegybankot. Az előzőre példa Korea, és Egyesült Királyság (1997), Ausztrália, és Japán (1998), Belgium (2004) és Svájc (2009), míg az utóbbit olyan tagállamok valósították meg leginkább, akik szerettek volna csatlakozni az euró-övezethez, arra tekintettel, hogy - mivel a csatlakozást követően megszünik a monetáris politikai alapfunkciójuk - a felügyelet átadása se jelentsen dilemmát (Írország, Hollandia stb.).

\section{A válság előtt, néhány meghatározó ország megoldása a felügyeleti hatáskör ellátására}

1. táblázat

\begin{tabular}{|c|c|c|c|}
\hline \multicolumn{2}{|c|}{ Jegybank a felügyeleti hatóság } & Nem a jegybank látja el a felügyeletet \\
\hline $\begin{array}{c}\text { Kizárólag a jegybank } \\
\text { látja el }\end{array}$ & Partikuláris & Egységes & Partikuláris \\
\hline Olaszország & Portugália & Dánia & Finnország \\
\hline Németország & Hollandia & Anglia & Franciaország \\
\hline Írország & Görögország & Svédország & \\
\hline Belgium & Spanyolország & Ausztria & \\
\hline & & Luxemburg & \\
\hline
\end{tabular}

Forrás: http://www.bankszovetseg.hu/wp-content/uploads/2012/10/032Sipos.pdf

Több tagállam törvényhozása szembesült azzal a dilemmával, hogy integrált vagy elkülönült modell lenne-e hatékonyabb a felügyeleti feladatok ellátására. Ennek eredményeképpen egy igen sokszínü és változatos rendszer jött létre.

A tagállamok többsége az integrált modellt választotta, ami a pénzügyi felügyelet megerősítését és a felügyelet jegybank alá integrálását jelentette, így immáron az összevont modellt választó országokban a jegybank felel a rendszerszintű kockázatok mérsékléséért és kezeléséért a pénzügyi rendszerben. Ezt a megoldást választották többek között például az írek, belgák, és a britek, a francia és a magyar (2013) felügyeleti reform is ennek vetette alá magát. Az elkülönült modellt kevesebb ország választotta, köztük például Lengyelország.

A makroprudenciális politika több szinten müködik. Van egy globális politikai szint, amelyet különböző nemzetközi szervezetek alkotnak, majd az ezek által meghatározott kereteken belül müködik az Európai Rendszerkockázati testület és a nemzeti hatóságok. 2013. július 1-ig hatályba kellett lépnie azon tagállami intézkedéseknek, amelyek meghatározzák, hogy mely nemzeti hatóság látja el a makroprudenciális feladatokat tagállami szinten, ki lesz felelős ezek felügyeletért. ${ }^{33}$

Magyarországon 2011-ben négy makroprudenciáliseszközta Magyar Nemzeti Bankra testáltak. A Magyar Nemzeti Bankról szóló 2013. évi CXXXIX. törvény alapján létrejött Magyarországon a Pénzügyi Stabilitási Tanács (az MNB döntéshozó szerve), amely feladata többek között a mikro- és makroprudenciális felügyelet közötti összhang megteremtése, valamint ebben az évben történt meg a felügyeleti feladatok integrálása is a MNB alá, amellyel Magyarország az összevont modellt alkalmazó államok csoportjába került. Összességében az a véleményem, hogy több előnye, mint hátránya van ennek a megoldásnak. Jóllehet egy bonyolult rendszerről van szó, és fokozottabban ügyelni kell a MNB

\footnotetext{
33 NEMÉNYI JUDIT: A pénzügyi válság hatása a központi bankok szabályozására. Elérhető: http://econ.core.hu/file/download/vesz2011/kozpontibankok.pdf (2015.07.27.)
} 
függetlenségének érvényesülésére, de ez a beolvadás egyszerübbé tette a jegybank és a felügyelet közötti együttműködés megteremtését, a jegybank erős függetlensége által erősödik a felügyeleti hatáskör, illetve ez a rendszer költséghatékonyabb, mint elődje, mivel egy intézmény látja el a két feladatot.

A jegybankok felügyeleti hatáskörrel való felruházása mellett szól, hogy a jelentős szakmai potenciállal rendelkező központi bankok azáltal, hogy új feladatokat látnak el, azok viteleútján hatékonyabbá tehetik a monetáris politikai döntéseket is. Viszont az is megállapítható, hogy míg a monetáris hatóságnak a monetáris politikához kapcsolódó hatásköreit függetlenül kell gyakorolnia, addig a pénzpiacok prudenciális felügyelete a kormányzat felhatalmazásán alapszik és függ attól. A jegybank függetlenségét biztosítja, hogy a kormányok nem utasíthatják őket a monetáris politikával kapcsolatban (pl.: konkrét kamatdöntést illetően), továbbá, hogy megfelelő pénzügyi forrásokat biztosítanak feladatai ellátására.

A MNB felügyeleti hatáskörében eljárva 2015. április 17-én visszavonta a Quaestor Értékpapírkereskedelmi és Befektetési Zrt. tevékenységi engedélyét, és 2015. április 22-én kezdeményezte annak felszámolását. ${ }^{34}$ (A felszámolás elrendelésének oka az volt, hogy az Értékpapír-kereskedelmi és Befektetési Zrt. visszaélt ügyfelei bizalmával, azzal, hogy azt a látszatot keltette, mintha az embereknek a pénzükért cserébe Quaestor kötvényt helyezett volna el a nála megnyitott értékpapírszámlán, pedig valójában valós értékpapírt nem adott cserébe. A visszaélést a felügyeleti feladatokat ellátó MNB tárta fel. A Quaestor károsultak kárrendezését biztosító követeléskezelő alap létrehozásáról szóló 2015. évi XXXIX. törvényt az országgyülés 2015. április 14-én fogadta el. A törvény hatálya azokra az ügyletekre terjed ki, amelyeknél az ügyfél jognyilatkozata a QUAESTOR FINANCIAL HRURIRA Tanácsadó és Szolgáltató Korlátolt Felelősségü Társaság által kibocsátott, illetve a QUAESTOR Értékpapírkereskedelmi és Befektetési Zártkörűen Működő Részvénytársaság vagy kapcsolt vállalkozása által értékesített kötvények vásárlására irányul (amennyiben az ügyfél az ellenérték fizetési kötelezettségének eleget tett). Ezen törvény létrehozta a Quaestor Károsultak Kárrendezési Alapját, amelynek feladata a kárrendezés és, amely a Befektetővédelmi Alap (Beva) kártalanításával együtt - 30 millió forintig kárpótolja az ügyfeleket.

Problémát jelent azonban, hogy a Quaestor Károsultak Kárrendezési Alapjának közleménye szerint ${ }^{35}$ csak a Beva által fizetendő 20 ezer euróig kártalanítják a kötvényeseket, a 100 ezer euróig fennmaradó további összeg kifizetését az alap csak időben eltolva tudja teljesíteni, egyelöre csak a fiktív kötvények után.

Ennek oka, hogy az OTP indítványt terjesztett az AB elé, arra hivatkozással, hogy az Alapba történő befizetés alkotmányos jogokat sért, mivel a Buda-Cashtől és a Hungária Értékpapírtól eltérően a kormány a Quaestornál szinte teljes kártalanítást rendelt el a többi iparági szereplő pénzéböl. Korábban a Bankszövetség is felszólalt a quaestorosok kiemelt kárpótlása ellen. Wolf László, az OTP vezérigazgató-helyettese az alábbi kérdéseket tette fel: „,volt-e egyáltalán kötvény? Ha nem volt, akkor az miért befektetési szolgáltatás? Ha viszont tiltott betétgyüjtés zajlott, akkor miért a Beva fizet? Az MNB bő három hónapja miért adott minderre engedélyt? Miért nem támogatja a jegybank a lakosság pénzügyi tudatosságának fejlődését? Lényegében visszafizetünk mindent azoknak, akik éveken át rendkívül kockázatos termékbe fektettek, és bátorságukért magas hozamot kaptak egy szabálytalan kibocsátótól. Az is különös, hogy a Buda-Cash ügyfeleire sem koncentrált ennyire az állam. Kicsit olyan ez, mintha egy biztosítás alapszabályát szeretném úgy módosítani, hogyha reggel összetöröm a kocsimat, délután még tudok rá visszamenőleg érvényes biztosítást kötni.”

\footnotetext{
${ }^{34}$ A Pénzügyi Stabilitási és Felszámoló Nonprofit Kft. közleménye a felszámolás elrendeléséröl: http://www.psfn.hu/hirek/2015 Quaestor.html (2015.07.27.)

${ }^{35} \mathrm{http}: / / w w w . p o r t f o l i o . h u /$ users/elofizetes info.php? $\mathrm{t}=$ cikk\&i=216590 (2015. 07. 27.)
} 
Azonban a bíróság elé terjesztett indítvány sokak (beleértve OTP-t is) szerint nem nyomós ok a kifizetés eltolására, mivel az $\mathrm{AB}$ eljárása a hatályos jogszabályok szerint nincs ráhatással egy hatályos törvény végrehajtására.

$\mathrm{Az} \mathrm{AB}$ döntése októberre várható, addig a károsultaknak be kell érniük a BEVA általi maximum 6 millió forintig terjedő kártalanítással, illetve ha az AB elkaszálja a törvényt, akkor nincs mit tenni és ezen összeggel kell megelégedniük az igénylőknek. 